DOI https://doi.org/10.30525/978-9934-26-074-2-68

\title{
ОКРЕМІ ПИТАННЯ ВИЗНАЧЕННЯ СУБ'СКТІВ, УПОВНОВАЖЕНИХ НА ВЧИНЕННЯ ПРОЦЕСУАЛЬНИХ ДІЙ В ЕКСТЕРИТОРІАЛЬНОМУ ПРОСТОРІ УКРАЇНИ
}

\author{
Рибицька О. М. \\ аспірант кафедри кримінально-правових дисциплін \\ юридичного факультету \\ Харківського національного університету імені В. Н. Каразіна \\ м. Харків, Украӥна
}

Кримінальне провадження в екстериторіальному просторі провадження, яке здійснюється за територіальними межами України, а саме на території дипломатичних представництв, консульських установ України, на повітряному, морському чи річковому судні, що перебуває за межами України під прапором або з розпізнавальним знаком України, якщо це судно приписано до порту, розташованого в Україні, з визначеним колом процесуальних дій, повноваженнями для здійснення яких наділені спеціальні суб'єкти, визначені в законі.

Досліджуючи проблематику кримінального провадження в екстериторіальному просторі, важливими питаннями $\epsilon$ визначення екстериторіального простору, кола суб'єктів, уповноважених на вчинення процесуальних дій, та повноважень, якими вони наділені під час цих дій. Зважаючи на те, що кримінальне процесуальне законодавство не регламентує у повній мірі питання суб'єктів, уповноважених на вчинення процесуальних дій, а наукове співтовариство веде дискусії та не прийшло до одного варіанту вирішення цієї проблематики, в цьому і полягає актуальність дослідження.

У кримінальному процесуальному кодексі України, прийнятому у 2012 році (далі -КПК України), передбачений цілий розділ для регламентації питань щодо кримінального провадження в екстериторіальному просторі.

Згідно із ст. 519 КПК України службовими особами, уповноваженими на вчинення процесуальних дій, $\epsilon$ :

1) керівник дипломатичного представництва чи консульської установи України або визначена ним службова особа - у разі вчинення кримінального правопорушення на території дипломатичного представництва чи консульської установи України за кордоном.

2) капітан судна України -у разі вчинення кримінального правопорушення на повітряному, морському чи річковому судні, що 
перебуває за межами України під прапором або 3 розпізнавальним знаком України, якщо це судно приписано до порту, розташованого в Україні.

Керівник дипломатичного представництва чи консульської установи України, капітан судна України зобов'язаний призначити іншу службову особу, уповноважену на вчинення процесуальних дій, якщо він є потерпілим внаслідок вчинення відповідного кримінального правопорушення.

Службові особи, які здійснювали процесуальні дії, залучаються як свідки до кримінального провадження після його продовження на території України. Вони зобов'язуються надавати пояснення слідчому, прокурору щодо проведених процесуальних дій [1].

Досліджуючи зміст даної статті, можна стверджувати про суперечність відповідних положень кримінального-процесуального законодавства. Так, у ч. 1 ст. 519 КПК України законодавець зазначає: «службовими особами, уповноваженими на вчинення процесуальних дій, $є$ : «і далі ми розуміємо, що йдеться про керівника дипломатичного представництва чи консульської установи, капітана повітряного, морського, річкового судна. Спираючись на це, можна було б дійти висновку, що ніби-то і визначено вказане коло суб'єктів, уповноважених на вчинення процесуальних дій, але як зазначається у п. 1 і п. 2 ч. 1 ст. 519 КПК України службовими особами є керівник дипломатичного представництва чи консульської установи України, капітан повітряного, морського чи річкового судна або визначена ним службова особа. Ось тут і прослідковується вищевказана суперечність, i не тільки лінгвістична, але і юридична, адже формулюючи визначення службової особи, законодавець називає службову особу, але не конкретизує ії. Як для наукової спільноти, так і для правоохоронних органів законодавець створює дисперсію в розумінні і чіткому визначенні суб'єктів, уповноважених на вчинення процесуальних дій у кримінальному провадженні в екстериторіальному просторі. Також у ч. 2 ст. 519 КПК України вказується на обов'язковість призначення іншої службової особи, уповноваженої на вчинення процесуальних дій, якщо вказані службові особи (керівник дипломатичного представництва чи консульської установи України, капітан судна) стали потерпілими внаслідок вчинення відповідного кримінального правопорушення. Аналізуючи це положення, законодавець обумовлює ще більше запитань, ніж дає відповідей, адже якщо ми говоримо про таке кримінальне правопорушення як вбивство керівника дипломатичної установи чи, наприклад, капітана повітряного судна, ці службові особи фізично не зможуть визначити службову особу, уповноважену на вчинення процесуальних дій. Хто за таких обставин $з$ дипломатичного представництва чи екіпажу судна буде наділений відповідними повноваженнями? Дослі- 
джуючи дану проблематику, ні в кримінальному процесуальному законі, ні в іншому національному законодавстві, ні в міжнародних договорах, ратифікованих Верховною Радою України, регламентація механізму заміщення однією службової особи на іншу, уповноважену на вчинення процесуальних дій, відсутня. Доречно постає питання - як юридично має відбуватись призначення однією службовою особою іншої службової особи? Який процесуальний документ має бути складений? Чи вистачить для цього лише усної заяви?

Досліджуючи ст. 19 Віденської конвенції про дипломатичні зносини 1961 року, а саме, якщо пост глави представництва вакантний або якщо глава представництва не може виконувати своїх функції, тимчасово виконуючим обов'язки голови представництва $є$ тимчасовий повірений у справах. У тих випадках, коли жоден дипломатичний співробітник представництва не знаходиться в державі перебування, член адміністративно-технічного персоналу може, за згодою держави перебування, бути призначений акредитуючою державою, відповідальним за ведення поточних адміністративних справ представництва [2]. Також проаналізувавши ст. 15 Віденської конвенції про консульські зносини 1963 року, в якій зазначається, що якщо керівник консульської установи не може виконувати своїх функції, у разі, якщо посада керівника консульської установи $є$ вакантною, функції керівника консульської установи можуть тимчасово виконуватися виконуючим обов'язки керівника консульської установи [3].

Вище вказане дає можливість сформулювати висновок, згідно з яким наявна відповідна суперечність та не визначеність у законодавстві. Враховуючи можливість заміщення посади керівника дипломатичного представництва та керівника консульської установи України у вищевказаних Віденських конвенціях вважається доречним внесення відповідних змін до кримінального процесуального законодавства України, а саме - конкретизувати і розширити коло суб'єктів, уповноважених на вчинення процесуальних дій на території дипломатичного представництва чи консулької установи України. Таким чином, п. 1 ч. 1 ст. 519 КПК України пропонується викласти в наступній редакції:

Службовими особами, уповноваженими на вчинення процесуальних дій, $є$ :

1) керівник дипломатичного представництва чи консульської установи України або визначена ним службова особа (тимчасовий повірений у справах, член адміністративно-технічного персоналу, виконуючий обов'язки керівника консульської установи в разі його відсутності) - у разі вчинення кримінального правопорушення на території дипломатичного представництва чи консульської установи України за кордоном». 


\title{
Література:
}

1. Кримінальний процесуальний кодекс України: Закон України від 13.04. 2012p. № 4651-VI. URL: https://zakon.rada.gov.ua/laws/show/465117\#Tеxt (дата звернення 01.04.2021).

2. Віденська конвенція про дипломатичні зносини: Конвенція від 18.04.1961 p. URL: https://zakon.rada.gov.ua/laws/show/995_048\#Text (дата звернення 01.04.2021).

3. Віденська конвенція про консульські зносини: Конвенція від 24.04.1963 p. URL: https://zakon.rada.gov.ua/laws/show/995_047\#Text (дата звернення 01.04.2021).

DOI https://doi.org/10.30525/978-9934-26-074-2-69

\section{КРИМІНАЛЬНО-ПРОЦЕСУАЛЬНЕ ДОКАЗУВАННЯ: УКРАЇНА, ФРН, США}

\author{
Савчук М. А. \\ orcid.org/0000-0002-3467-4690
}

викладач кафедри кримінально-правових дисииплін

Криворізький навчально-науковий інститут

Донеиького юридичного інституту

Мінстерства внутрішніх справ Украйни,

адвокат

м. Кривий Ріг, Дніпропетровська область, Україна

\author{
Часова T. 0. \\ orcid.org/0000-0002-0293-6123 \\ кандидат юридичних наук,
}

дочент кафедри кримінального права, прочесу та криміналістики

Академії прачі, сочіальних відносин і туризму,

адвокат

м. Київ, Украӥна

Центральне місце у кримінально-процесуальному праві відведено інституту доказування. Доказування $\epsilon$ складним за процедурою механізмом, який складається 3 декількох етапів: збирання, оцінка та застосування доказів під час розслідування. Дотримання належної процедури фактично допомагає встановити що саме належить до категорії доказів, яким чином їх слід процесуально закріпити та в подальшому, щоб це призвело до їх використання у судовому процесі. 